Original articles

https://www.journal-imab-bg.org

\title{
INVESTIGATION OF IMMUNOSUPPRESSED PATIENTS FOR THE PRESENCE OF EBV DNA IN REAL TIME PCR
}

\author{
Tsvetelina Kostadinova ${ }^{1}$, Liliya Ivanova ${ }^{2}$, Zhivka Stoykova ${ }^{2,}$, Tatina Todorova ${ }^{3}$, \\ Liana Gercheva ${ }^{4}$, Dobromir Staykov ${ }^{5}$, Denitsa Tsaneva ${ }^{6}$, \\ 1) Education and Research Sectors of Medical Laboratory Assistant, Medical \\ College, Medical University, Varna, Bulgaria \\ 2) Laboratory of Clinical Virology - University hospital "St. Marina", Varna, \\ Bulgaria \\ 3) Department of Preclinical and Clinical Sciences, Faculty of Pharmacy, \\ Medical University, Varna, Bulgaria \\ 4) Clinic of Hematology at the University Hospital St. Marina - Varna \\ 5) Regional Center of Transfusion Hematology - Varna \\ 6) Department of Microbiology and Virology, Faculty of Medicine, Medical \\ University Varna, Bulgaria.
}

\section{ABSTRACT}

Epstein-Barr virus (EBV) reactivates during immunosuppression (IS) and immune deficiency. The introduction of stem cell transplantation and the development of transplantology require compliance with criteria for assessing the risk of reactivation of latent viral infections, including EBV. There are no published EBV DNA findings in Bulgaria for such patient groups,

Aim: The aim in this study is to assess the possible benefit of EBV PCR testing in immunosuppressed individuals.

Materials and Methods: We investigated 50 immunosuppressed patients - 28 with various haematological diseases, 17 after kidney transplantationand5 patients with autologous stem cell transplantation (HSCT). Patients were first tested in an indirect ELISA to detect anti-VCA IgM/IgG (Euroimmun, Luebeck, Germany) and then in quantitative PCR (Sacace Biotechnologies S.r.1., Como, Italy).

Results: We found EBV DNA in $14.0 \%(95 \%$ CI:5.8\% $-26.7 \%, n=7$ ) of all tested patients. The Real time PCR results were in the range $100-500$ copies $/ \mathrm{ml}$ at the lower limit of the 500 copies/ml test positivity. The highestistheproportionofpatientswithhaematological diseases $(21.4 \%)$, predominantly with AML.

Conclusion: We found a relatively small proportion of IS patients with detectable EBV DNA. For HSC-transplanted patients, we anticipate probable reactivation or reinfection in one patient, who was anti-VCA IgG positive in the primary study.

Keywords: Epstein-Barr virus, Immunosuppressed patients, Acute myeloid leukaemia, Kidney transplantation, Autologous hematopoietic stem cells transplantation, Real time PCR,

\section{INTRODUCTION}

It has been well established that cell-mediated immunity is important for the control of EBV reactivation. Immunosuppressed and immunocompromised patients are at high risk of viral reactivation and of EBV associated malignancies, accompanied by increased viral replication and the number of virus infected cells $[1,2]$. On the other hand, these patients are considered to be at risk of infection with different strains of EBV [3]. Serological methods are not relevant in the diagnosis of EBV infection in immunocompromised and immunosuppressed patients due to dysfunction of the immune system and appearance of atypical serological profiles [4]. The PCR method is a method of choice and may have prognostic value for patients with detectable EBV DNA [1]. We investigated the viral load in patients mainly with hematological diseases and patients that have undertaken transplantations, to determine the risk of EBV reactivation. We believe that data collection across different patient groups will help create practical diagnostic algorithms for controlling and managing viral infections.

\section{MATERIALS AND METHODS}

We investigated 50 immunosuppressed patients 28 with various haematological diseases (56\%), 17 after kidney transplantation (34\%) and5 patients with autologous stem cell transplantation (HSCT) (10\%). In this study, we did not include patients with Hodgkin's and NonHodgkin's lymphomas. A plasma sample of patients with stem cell transplantation was taken once withinthe the first month after the transplantation.

Indirect ELISA tests for anti-VCA IgM/IgG (Euroimmun, Luebeck, Germany) were used according to the standard instructions described in the test protocol.

For the Real time PCR, DNA was extracted in 150 
ìl plasma samples (Kit RiboVirus, Sacace Biotechnologies S.r.l., Como, Italy). The target region in the viral genome was amplified with EBV Real-TM Quant(Sacace Biotechnologies S.r.l., Como, Italy) in reaction volumes of 25ìl and using the QuantStudioDx Real-Time PCR Instrument (Thermo Fisher Scientific, Waltham, MA USA). The average age of the sample, the proportions and the confidence intervals were determinedwith SPSS, vs 23.

\section{RESULTS}

The average age of all subjects was 46.4 years (SD \pm 18.3 ), range $3-80$ years. Individuals with hematological diseases predominated $(56.0 \%, \mathrm{n}=28)$. Their average age was 50.8 ( $\mathrm{SD} \pm 20.6)$. Of these, those diagnosed with acute myeloid leukemia (AML) prevailed- $82.1 \%$. The remaining patients were after kidney transplantation $-34.0 \%$ (n $=17$, average age $42.0 \pm 11.8$ years) and autologous stem cell transplantation (HSCT) $-10.0 \%(\mathrm{n}=5$, average age $36.8 \pm 19.1)$.

We have data on anti-VCA IgM/IgG in ELISA for 36 of the patients $(72.0 \%, 95 \%$ CI: $57.5 \%-83.8 \%)$. These were all patients with hematological diseases, stem cell transplant patients and three patients after renal transplantation. Positive in ELISA anti-VCA IgM were two patients - aged 6 years (HSCT) and 80 years (AML). All tested positive for anti-VCA $\operatorname{IgG}$, indicating infection with the virus. Data according to the $\mathrm{RU} / \mathrm{ml}$ (relative units/ml) by age is presented in Figure 1. Values above $22 \mathrm{RU} / \mathrm{ml}$ are taken as positive according to the criteria used in the test.

Fig. 1. Comparative representation of reported RU/ $\mathrm{ml}$ by ages

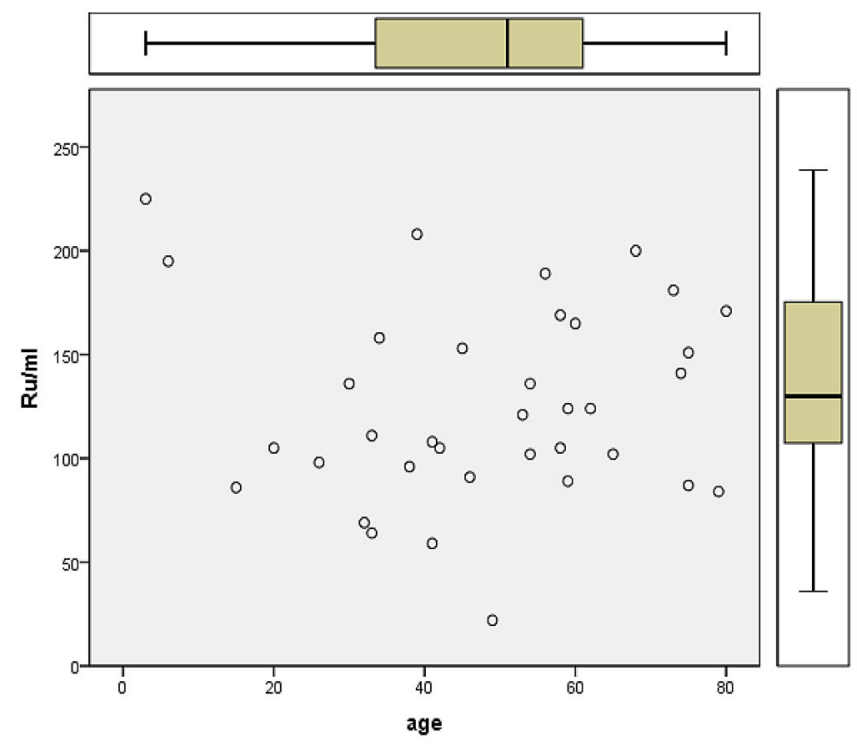

Presence of EBV DNA in Real-time PCR was found in $14.0 \%(95 \% \mathrm{CI}: 5.8 \%-26.7 \%, \mathrm{n}=7)$ of those tested (Table 1). All patients were in the range 100-500 copies/ $\mathrm{ml}$ at the lower limit of the 500 copies/ml test positivity.

Table 1. Characteristics of IS patients with detectable EBV DNA in Real-time PCR

\begin{tabular}{|l|c|c|}
\hline Patients & Detectable EBV DNA n $(\%)$ & Negative EBV DNA n $(\%)$ \\
\hline Renal transplanted & 0 & $17(100 \%)$ \\
\hline HSCT & $1(20 \%)$ & $4(80 \%)$ \\
\hline Haematological diseases & $6(21.4 \%)$ & $22(78.6 \%)$ \\
\hline
\end{tabular}

The average age of patients with detectable viral DNA in the PCR was 52.4 years $(\mathrm{SD} \pm 33.57)$. Highest values (approximately 500 copies $/ \mathrm{ml}$ ) occurred in the eldest patient - 80 years (AML). We detected viral DNA in both patients positive in the anti-VCA IgM assay. Comparison of the results of anti-VCA Ig G in RU/ml and EBV DNA in copies/ml is presented in Figure 2.
Fig. 2. Comparative representation of quantitative anti-VCA IgG in RU/ml and viral load in copies/ml

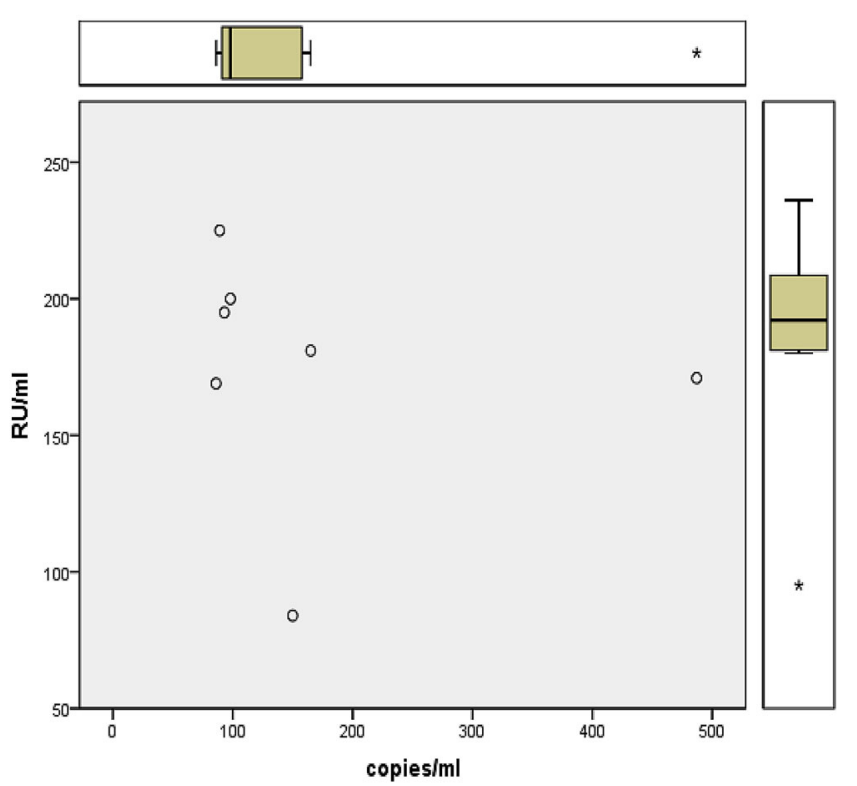




\section{DISCUSSION}

In the current study, we found a lower proportion of immunosuppressed patients with detectable EBV DNA. Since the group was heterogeneous, we compared the results according to the clinical diagnosis. The highest proportion of detectable viral DNA was obtained in patients with hematological diseases (five of them had a clinical diagnosis of AML). In another study, we found a significantly higher proportion of EBV DNA positive patients with Hodgkin's lymphoma $(40.7 \%)$ and non-Hodgkin's lymphoma $(15.4 \%)$ with higher viral load (unpublished data).Clinical cases have been reported with the detection of EBV DNA mainly in patients with acute lymphoblastic leukemia and chronic myeloid leukemia, more commonly in childhood [5]. It is believed that there is an increased risk of acute lymphoblastic leukemia in children under one year due to maternal EBV infection during pregnancy [6], although other authors reject his [7]. In 47 patients with different hematological diseases, including lymphomas, and other immunosuppression the authors found viral reactivation with a wide range of viral load. The outcome for most patients was fatal, and many opportunistic infections were described. In 7/12 patients the CMV viremia occurred within 1 month of the EBV viremia and the other opportunistic infections were found within 2 months of first positive results. Fludarabine and alemtuzumab, commonly used in therapy, are believed to have an additional suppressive effect on $\mathrm{T}$ cell immunity and are a possible cause of EBV reactivation [1]. There is a high risk of common subclinical EBV, HCMV and HHV6 reactivations in T-cell leukemia. The authors state that reactivations of HHV-6 and EBV are self-limiting. They do not associate with a particular disease, and patients do not experience reduced survival [8]. Other authors suggest that with new immunosuppressive regimens, more potent immunosuppressive agents or multiple treatments, the increased demand for EBV and CMV is warranted [9].The amount of viral load we have found is very low, and this would not affect the prognosis of the disease, but our studies were very limited. It is necessary to accumulate more data on the risks of reactivation of viral infection in such patients and additional evidence of connection between the virus and leukemia.

There is significantly more information on the risks of EBV infection and its reactivation in immunosuppressed patients after HSCT and solid organ transplantation (SOT). In renal transplant patients, we did not detect EBV DNA. Based on the literature, the incidence of PTLD (Posttransplant lymphoproliferative disorder) after SOT is about $1 \%$ to $2.3 \%$, the latest data is being obtained by observing a significant number of patients $(n=1537)$ [10]. The time for extracting plasma post-transplant, the small sample size and the single point testing are factors that may have affected our results. Over 10 years of observation of a large cohort of transplant patients in France found that the risk of development of PTLD was high in the first and after the 8th year. EBV was found to cause early posttransplant complications and was associated with the first peak [11]. A higher incidence has been demonstrated in seronegative recipients, which means that children are at higher risk [12]. In a preliminary analysis of the onset of primary infection, we found that EBV distribution in Bulgaria follows the model of developed countries. This means that a large population of children and young people is seronegative [13].

A higher risk of developing PTLD (between $1 \%$ and $3 \%$ ) occurs with allogenic HSCT transplantation [14]. After HSCT, the median onset of PTLD is after 2 months, whereas after the SOT is a 6th month [15]. Our data is from autologous transplant patients. In these cases, the risk of reactivation is insignificant, and the current standards do not include EBV DNA monitoring [16, 17, 18]. We have studied relatively few patients, and plasma EBV DNA was found at one, examined at the end of the first month after transplantation, without being traced in dynamics. Serological studies a month later showed an anti-VCA IgM positive and anti-VCA IgG positive profile. Initial serostatus shows evidence of EBV infection and does not define primary infection. This single case is not enough to draw conclusions about post-transplantation follow-up of autologous transplantation cases. Other authors also identified EBV DNA after autologous stem cell transplantation in 5 patients [1]. Initial serostatus registration in ELISA before transplantation is a mandatory procedure. In interpreting the serology data, the immune status of the patient should be considered due to the fact that immunosuppression may delay the humoral response to EBV antigens and may suppress the IgM formation. Consideration should also be given to the presence of haemotransfusions [16], with which the titer of $\mathrm{IgG}$ increases because of the passively acquired antibodies. Post-transplantation monitoring should be continued, with particular attention to seronegative cases. PCR is now a routine method in diagnostic laboratories, and there should be no restrictions on its use.

\section{CONCLUSION}

We found a small proportion of detectable EBV DNA $(14.0 \%)$ in IS patients. Viral copies are in very low quantities. The highest is the proportion of patients with clinical diagnosis of AML. Among the HSC transplants, one patient seropositive in the primary study may have reactivation or reinfection. EBVDNA post-transplant monitoring can define cases of viral reactivation and help prevent and treat possible complications. 


\section{REFERENCES:}

1. Martelius T, Lappalainen M, Aalto SM, Nihtinen A, Hedman K, Anttila VJ. Clinical characteristics, outcome and the role of viral load in nontransplant patients with EpsteinBarr viraemia. Clin Microbiol Infect. 2010 Jun;16(6):657-62. [PubMed] [CrossRef]

2. Adler B, Schaadt E, Kempkes B, Zimber-Strobl U, Baier B, Bornkamm GW. Control of Epstein-Barr virus reactivation by activated CD40 and viral latent membrane protein 1. Proc Natl Acad Sci U S A. 2002 Jan 8;99 (1):437-42. [PubMed] [CrossRef]

3. Tsai M-H, Lin X, Shumilov A, Bernhardt K, Feederle R, Poirey R, et al. The biological properties of different Epstein-Barr virus strains explain their association with various types of cancers. Oncotarget. 2017 Feb;8(6):10238-10254. [PubMed] [CrossRef]

4. De Paschale M, Clerici P. Serological diagnosis of Epstein-Barr virus infection: Problems and solutions. World J Virol. 2012 Feb;1(1):31-43. [PubMed] [CrossRef]

5. Elawad HE, Kafi SK, Elrahman IA, Elzaki SG, Eljaili A, Ornasir ME, et al. The Possible Involvement of Epstein -Barr virus In the Etiology of Leukemia. J Med Microb Diagn. 2014; 4(1):174. [Internet]

6. Tedeschi R, Bloigu A, Ogmundsdottir HM, Marus A, Dillner $\mathrm{J}$, dePaoli P, et al. Activation of maternal Epstein-Barr virus infection and risk of acute leukemia in the offspring. Am J Epidemiol. 2007 Jan 15;165(2): 134-7. [PubMed] [CrossRef]

7. Tedeschi R, Luostarinen T, Marus A, Bzhalava D, Ogmundsdottir HM, Dillner J, et al. No risk of maternal EBV infection for childhood leukemia. Cancer Epidemiol Biomar- kers Prev. 2009 Oct;18(10):2790-2. [PubMed] [CrossRef]

8. Ogata M, Satou T, Kawano R, Yoshikawa T, Ikewaki J, Kohno K, et al. High incidence of cytomegalovirus, human herpesvirus-6, and EpsteinBarr virus reactivation in patients receiving cytotoxic chemotherapy for adult $\mathrm{T}$ cell leukemia. J Med Virol. 2011 Apr;83(4):702-9. [PubMed] [CrossRef]

9. Scheinberg P, Young NS, Barrett J. Response: EBV reactivation in the immunosuppressed: to treat or not to treat? Blood. 2008; 111(3):1739-40. [CrossRef]

10. Taylor AL, Marcus R, Bradley JA. Post-transplant lymphoproliferative disorders (PTLD) after solid organ transplantation. Crit Rev Oncol Hematol. 2005 Oct;56(1):155-67. [PubMed] [CrossRef]

11. Caillard S, Lamy FX, Quelen C, Dantal J, Lebranchu Y, Lang P, et al. Epidemiology of Posttransplant Lymphoproliferative Disorders in Adult Kidney and Kidney Pancreas Recipients: Report of the French Registry and Analysis of Subgroups of Lymphomas. Am J Transplant. 2012 Mar; 12(3):682-93. [PubMed] [CrossRef]

12. Mynarek M, Schober $\mathrm{T}$, Behrends U, Maecker-Kolhoff B. Posttransplant lymphoproliferative disease after pediatric solid organ transplantation. Clin Dev Immunol. 2013;2013:814973. [PubMed] [CrossRef]

13. Kostadinova Ts, Ivanova L, Raykov T, Stojkova Z, Tsankova G. Seroprevalence of Epstein-Barr Virus in North-Eastern Bulgaria. Acta Microbiol Bul. 2016,32: 33-38.

14. Styczynski J, Gil L, Tridello G, Ljungman P, Donnelly JP, van der Velden W, et al. Response to rituxi- mab-based therapy and risk factor analysis in Epstein Barr Virus-related lymphoproliferative disorder after hematopoietic stem cell transplant in children and adults: a study from the Infectious Diseases Working Party of the European Group for Blood and Marrow Transplantation. Clin Infect Dis. 2013 Sep;57(6):794-802. [PubMed] [CrossRef]

15. Gulley M, Tang W. Using Epstein-Barr Viral Load Assays To Diagnose, Monitor, and Prevent Posttransplant Lymphoproliferative Disorder. Clin Microbiol Rev. 2010 Apr; 23(2):350-66. [PubMed] [CrossRef]

16. Allen U, Alfieri C, Preiksaitis J, Humar A, Moore D, Tapiero B, et al. Epstein-Barr virus infection in transplant recipients: Summary of a workshop on surveillance, prevention and treatment. Can J Infect Dis. 2002 Mar; 13(2):89-99. [PubMed]

17. Styczynski J, Reusser P, Einsele $\mathrm{H}$, de la Camara R, Cordonnier C, Ward KN, et al. Management of HSV, VZV and EBV infections in patients with hematological malignancies and after SCT: guidelines from the Second European Conference on Infections in Leukemia, for the European Conference on Infections in Leukemia. Bone Marrow Transplant. 2009 May;43(10): 757-70. [PubMed] [CrossRef]

18. Styczynski J, van der Velden W, Fox CP, Engelhard D, de la Camara R, Cordonnier $\mathrm{C}$, et al. Management of Epstein-Barr Virus infections and posttransplant lymphoproliferative disorders in patients after allogeneic hematopoietic stem cell transplantation: Sixth European Conference on Infections in Leukemia (ECIL-6) guidelines. Haematologica. 2016 Jul;101(7):80311. [PubMed] [CrossRef]

Please cite this article as: Kostadinova T, Ivanova L, Stoykova Z, Todorova T, Gercheva L, Staykov D, Tsaneva D. Investigation of immunosuppressed patients for the presence of EBV DNA in Real time PCR. J of IMAB. 2018 JulSep;24(3):2129-2132. DOI: https://doi.org/10.5272/jimab.2018243.2129

Received: 22/05/2018; Published online: 28/08/2018

\section{Address for correspondence:}

Tsvetelina Kostadinova, MD, PhD

Education and Research Sectors of Medical Laboratory Assistant, Medical College, Medical University,

84 Tsar Osvoboditel Blvd., Varna, Bulgaria

E-mail: ckostadinova@abv.bg 